\title{
Inhibition of fertilization in vitro by treatment of rabbit spermatozoa with univalent isoantibodies to rabbit sperm hyaluronidase
}

\author{
Bonnie S. Dunbar, ${ }^{*}$ M. Gladys Muñoz, $\dagger$ \\ C. T. Cordle and C. B. Metz \\ Institute for Molecular and Cellular Evolution, University of Miami, Coral Gables, \\ Florida 33134, U.S.A.
}

Isoantibodies to whole semen or epididymal spermatozoa of rabbits inhibit fertilization in vitro (Russo \& Metz, 1974a). This inhibition is attributed to a primary blocking of one or more sperm antigens essential for the sperm-egg interaction, and not to a secondary action (e.g. agglutination, complement-dependent immobilization), because univalent (Fab) antibody fragments, which do not agglutinate or immobilize spermatozoa, are also effective. Hyaluronidase, the sperm enzyme required for penetration of the cumulus surrounding the egg, could be one such sperm antigen. This possibility is supported by the fact that cumulus dispersion was inhibited in the experiments of Russo \& Metz (1974a) and that hyaluronidase-inhibiting antibodies are present in isoantisera to rabbit semen (Metz, Seiguer \& Castro, 1972). It is necessary to employ antibody preparations specific for rabbit sperm hyaluronidase to examine critically the inhibition of fertilization by antihyaluronidase antibodies. We report here such inhibition of rabbit fertilization in vitro by Fab isoantibodies to purified rabbit sperm hyaluronidase.

\section{Methods}

Hyaluronidase was purified from rabbit epididymides (Pel-Freez, Rogers, Arkansas). These were homogenized in batches of approximately $200-300$ in $500 \mathrm{ml}$ triton-X buffer $\left(0 \cdot 1 \mathrm{M}-\mathrm{PO}_{4}, 0 \cdot 15\right.$ $\mathrm{M}-\mathrm{NaCl}, 0.1 \%$ Triton-X, $\mathrm{pH} 5.3$ ) using a Waring-type blender. After further homogenization in a glass homogenizer the material was frozen and thawed $(10$ cycles $)$ and centrifuged $(10,000 \mathrm{~g}, 30 \mathrm{~min}$, $4^{\circ} \mathrm{C}$ ). The hyaluronidase in the supernatant was purified by a modification of the procedure of Borders \& Raftery (1968); an initial precipitation with $50 \%$ saturated $\left(\mathrm{NH}_{4}\right)_{2} \mathrm{SO}_{4}$ was followed by DEAE chromatography. Hyaluronidase activity was determined by the turbidimetric (Tolksdorf, McCready, McCullough \& Schwenk, 1949) or the N-acetylglucosamine (Aronson \& Davidson, 1967) assay procedure. The purity of the hyaluronidase obtained was tested for some preparations by acrylamide gel electrophoresis and immunodiffusion against isoantisera to whole semen of rabbits. The least pure hyaluronidase preparations (sp. act. 3600 turbidity reducing units/mg protein) used as immunizing antigens and so tested produced up to 6 protein-staining bands in acrylamide gel electrophoresis but only one precipitin band, which was identical to the band containing hyaluronidase activity in the acrylamide gel. It was therefore concluded that the hyaluronidase preparations were isoantigenically pure. Isoantisera were prepared by injecting virgin female rabbits of the New Zealand White breed once a week for 3-4 weeks with this isoantigenically pure hyaluronidase $(0.2-0.46 \mathrm{mg}$ in $0.5 \mathrm{ml}$ phosphate-buffered saline emulsified in $0.5 \mathrm{ml}$ complete Freund's adjuvant per injection). The isoantisera utilized from these rabbits strongly inhibited rabbit sperm hyaluronidase activity, and did not produce more than one precipitin band during immunodiffusion against concentrated sperm extract, or the immunizing antigen which was sometimes tested. These results are consistent with the monospecificity of the sera for rabbit sperm hyaluronidase. Controls included sera from the same

\footnotetext{
* Present address: Department of Zoology, University of Tennessee, Knoxville, Tennessee, U.S.A. $\uparrow$ Present address: Department of Embryology, Catholic University of Chile, Santiago, Chile.
} 
rabbits before injection (Group II, Table 1) and sera from virgin female rabbits injected with Freund's adjuvant-saline emulsion alone (Group III).

The IgG fraction of pooled sera was prepared by DEAE chromatography and confirmed by immunodiffusion against specific goat antisera to rabbit IgG, IgM and IgA (Cappel Laboratories) and digested with papain (Sigma Chemical Co.) as described by Porter (1959) to produce Fab fragments. The preparations were subsequently passed through Sephadex G-75 to remove any undigested globulin and the nonspecific cumulus-dispersing factor (Metz et al., 1972) and adjusted to $12 \mathrm{mg}$ protein/ $\mathrm{ml}$ in phosphate-buffered saline. The Fab preparations were dialysed against the ovum culture medium lacking bovine serum albumin for $12 \mathrm{hr}$ before the experiment.

Superovulation was induced by i.m. injection of 100 i.u. PMSG (Sigma) and 75 i.u. HCG (Ayerst) 3 days and $14 \mathrm{hr}$, respectively, before flushing the oviducts with culture medium to obtain eggs in cumulus (Brackett, 1969). The culture medium was that described by Brackett \& Williams (1968) except that sodium pyruvate was used instead of blood serum and streptomycin $(25 \mathrm{mg} / \mathrm{ml})$ was added.

Capacitated spermatozoa were obtained by flushing the uteri of virgin females $12 \mathrm{hr}$ after artificial insemination $\left(6 \times 10^{7}\right.$ spermatozoa/rabbit) and $18 \mathrm{hr}$ after injection with 75 i.u. HCG. The capacitated spermatozoa were centrifuged at about $500 \mathrm{~g}$ for $5 \mathrm{~min}$ and re-suspended in culture medium to concentration of $2 \times 10^{6} / \mathrm{ml}$. Of this sperm suspension, $0 \cdot 25 \mathrm{ml}$ was mixed with $1 \mathrm{ml} \mathrm{Fab}$ antibody or control globulin to a final Fab protein concentration of $6 \mathrm{mg} / \mathrm{ml}$. These sperm suspensions were incubated for $15 \mathrm{~min}$, centrifuged $(500 \mathrm{~g}, 5 \mathrm{~min}$ ) re-suspended in $2 \mathrm{ml}$ culture medium and finally added to $2 \mathrm{ml}$ culture medium containing one or more cumulus masses. Strong motility of all residual sperm samples was confirmed following insemination in vitro.

After addition of treated spermatozoa, the culture dishes were flooded with paraffin oil, covered and incubated in a $5 \% \mathrm{CO}_{2} /$ air atmosphere. All operations were performed in a room at a constant temperature of $37^{\circ} \mathrm{C}$. Culture dishes were examined for cleavage of eggs and condition of the cumulus 24-28 hr after insemination. Samples of sperm washings and media were tested for hyaluronidaseinhibiting activity to check for antibody excess after sperm treatment and to estimate carry-over into the final incubation medium.

\section{Results}

The results of four experiments are given in Table 1. Aliquots of one antibody IgG preparation were used in Exps 1-3. Immunodiffusion against goat antibodies to whole rabbit serum showed predominantly IgG with some additional serum protein. A second preparation of Fab antibody and control globulin from pooled sera of different isoimmunized rabbits was employed in Exp. 4. The sperm hyaluronidase-inhibiting activity of the latter Fab antibody globulin was 531 units/mg (Aronson \& Davidson, 1967). Immunodiffusion against specific antirabbit Ig classes gave precipitation only with IgG before papain digestion. Supernatants from all Fab antibody-treated sperm samples and culture fluids from inseminated ova at the end of the experiment slightly inhibited the hyaluronidase activity, indicating some antibody excess. Control culture fluid showed measurable hyaluronidase activity at the end of the incubation period.

There were marked differences in the cleavage results of eggs inseminated with spermatozoa treated with Fab antibody (Group I) and the control groups (II, III, IV) in all experiments (Table 1). Eggs from the donors of the capacitated spermatozoa cleaved, confirming the presence of capacitated spermatozoa and the adequacy of the culture medium to support early development. Acceptable physiological culture conditions were also indicated by the lack of cleavage and fragmentation when no spermatozoa were present (Group V).

It is concluded that Fab antihyaluronidase isoantibody effectively inhibited fertilization in vitro. The assumption, based on the observations of Metz, Seiguer \& Castro (1972), that inhibition of fertilization would result from failure of spermatozoa to penetrate the cumulus is consistent with the very limited cumulus-dispersing action of spermatozoa treated with Fab antibody (Table 1) even after incubation for $24 \mathrm{hr}$. However, low levels of excess Fab antihyaluronidase antibody were apparently carried into the culture media with the inseminating spermatozoa, and it is possible but unlikely that the antibody acted directly on the eggs. 
Table 1. Cleavage of rabbit eggs (no. cleaved/total treated) inseminated in vitro with spermatozoa treated with Fab antihyaluronidase isoantibody

\begin{tabular}{ccccccc}
\hline Experiment & $\begin{array}{c}\text { Group 1 } \\
\text { (sperm. }+ \\
\text { antihyaluroni- } \\
\text { dase) }\end{array}$ & $\begin{array}{c}\text { Group II } \\
\text { (sperm. }+ \\
\text { preimmune } \\
\text { serum) }\end{array}$ & $\begin{array}{c}\text { Group III } \\
\text { (sperm. }+ \\
\text { adjuvant) }\end{array}$ & $\begin{array}{c}\text { Group IV } \\
\text { (sperm. }+ \\
\text { culture } \\
\text { medium) }\end{array}$ & $\begin{array}{c}\text { Group V } \\
\text { (partheno- } \\
\text { genesis } \\
\text { control) }\end{array}$ & $\begin{array}{c}\text { Group VI } \\
\text { (eggs from } \\
\text { capacitators) }\end{array}$ \\
\hline 1 & $0 / 15( \pm)$ & $10 / 10(+++)$ & - & $8 / 12(+++)$ & $0 / 5(-)$ & $11 / 12$ \\
2 & $1 / 12(++)$ & $5 / 11(+++)$ & - & $3 / 5(+++)$ & $0 / 3(-)$ & $11 / 11$ \\
3 & $1 / 11( \pm)$ & $5 / 7(+++)$ & $7 / 11(++)$ & $4 / 5(+++)$ & $0 / 2(-)$ & $8 / 8$ \\
4 & $0 / 6( \pm)$ & $1 / 3(++)$ & $3 / 6(++)$ & $0 / 4(+++)$ & $0 / 1(-)$ & $1 / 1$ \\
Total & $2 / 44$ & $21 / 31$ & $10 / 17$ & $15 / 26$ & $0 / 10$ & $31 / 32$ \\
$\%$ Cleaved & $4 \cdot 5$ & 68 & 59 & 58 & 0 & 97 \\
\hline
\end{tabular}

Symbols in parentheses indicate degrees of cumulus dispersion at time of scoring for cleaved eggs: - , no cumulus dispersion; +++ , complete dispersion.

Our results suggest that substantially all of the functional hyaluronidase of capacitated spermatozoa in this system is blocked by the treatment with the Fab antibody to hyaluronidase. Sperm hyaluronidase is located in the acrosomal region of uncapacitated spermatozoa (Mancini, Alonso, Barquet, Alverez \& Neminirovsky, 1964; Morton, 1975). Some of this hyaluronidase is attached loosely to the sperm surface (O'Rand \& Metz, 1974), probably in equilibrium with free hyaluronidase (Swyer, 1947), some is strongly bound to sperm membranes (unpublished), and most is presumably stored in the acrosome body itself. Approximately $50 \%$ of the readily extractable hyaluronidase in living uncapacitated rabbit spermatozoa is accessible to inhibition by antibody (Metz et al., 1972). The 'inaccessible' hyaluronidase is presumably acrosomal hyaluronidase, at least some of which is normally released during the acrosome reaction in the vicinity of the cumulus before sperm-egg interaction. Additional 'inaccessible' hyaluronidase may be bound to the inner acrosomal membrane. In this connection it would be interesting to know if capacitated, Fab antihyaluronidase IgG-treated spermatozoa undergo an acrosomal reaction in the cultures with concomitant release of inaccessible hyaluronidase. If 'inaccessible' hyaluronidase was released in the present experiments it was evidently neutralized by excess Fab antihyaluronidase antibody.

Since antihyaluronidase antibodies inhibit fertilization in vitro of eggs from normal females, the reduced fertilizability in vitro of eggs from females isoimmunized with rabbit semen (Russo \& Metz, 1974b) could result, at least in part, from antihyaluronidase isoantibodies carried over from the follicular fluid of the isoimmunized egg donor. Isoimmunization of female rabbits with purified rabbit sperm hyaluronidase should produce a reduction in fertility in vivo ('antifertility vaccine' effect) if a significant amount of antihyaluronidase antibody is present at the site of sperm-egg interaction and if the cumulus does not disperse spontaneously before death of the spermatozoa or ova in the female tract.

This report is Contribution No. 290. The study was aided by Grant HD-06663 from the NICHD, U.S. Public Health Service, Grant M74-31 from the Population Council and Grant H9-181-162-A from the World Health Organization to C.B.M. The participation of M.G.M. was made possible by Ford Foundation Grant 720-0384 to Dr C. Barros, Catholic University of Chile. We thank Dr B. G. Brackett, for his interest and help, and Dr M. G. O'Rand, Dr C. Bradshaw-Sidran and Mr B. Bartram for some technical assistance.

\section{References}

Aronson, N.N. \& Davidson, E.A. (1967) Lysosomal hyaluronidase from rat liver. I. Purification. $J$. biol. Chem. 242, 437-440.

Borders, C.L. \& RAfTery, M.A. (1968) Purification and partial characterization of testicular hyaluronidase. J. biol. Chem. 243, 2756-3762.

BRACKeTt, B.G. (1969) Effects of washing the gametes on fertilization in vitro. Fert. Steril. 20, 127-142. 
Brackett, B.G. \& Williams, W. L. (1968) Fertilization of rabbit ova in a defined medium. Fert. Steril. 19, 144-155.

Mancini, R.E., Alonso, A., Barquer, J., Alverez, B. \& Neminirovsky, M. (1964) Histo-immunological localization of hyaluronidase in the bull testis. $J$. Reprod. Fert, 8, 325-330.

Metz, C.B., Seiguer, A.C. \& Castro, A.E. (1972) Inhibition of the cumulus dispersing and hyaluronidase activities of sperm by heterologous and isologous antisperm antibodies. Proc. Soc. exp. Biol. Med. 140, 776-781.

Morton, D.B. (1975) Acrosomal enzymes: immunochemical localization of acrosin and hyaluronidase in ram spermatozoa. J. Reprod. Fert. 45, 375-378.

O'RAND, M.G. \& METZ, C.B. (1974) Tests for rabbit sperm surface iron-binding protein and hyaluroni- dase using the 'exchange agglutination' reaction. Biol. Reprod. 11, 326-334.

PorTer, R.R. (1959) The hydrolysis of rabbit gammaglobulin and antibodies with crystalline papain. Biochem. J. 73, 119-126.

Russo, I. \& METz, C.B. (1974a) Inhibition of fertilization in vitro by treatment of rabbit spermatozoa with univalent isoantibody. J. Reprod. Fert. 38, 211215.

Russo, I. \& METZ, C.B. (1974b) In vitro fertilizability of rabbit ova from donors isoimmunized with sperm. J. exp. Zool. 187, 155-158.

SWYER, G.I.M. (1947) The release of hyaluronidase from spermatozoa. Biochem. J. 41, 413-417.

Tolksdorf, S., McCready, M.H., McCullough, D.R. \& Schwenk, S. (1949) The turbidimetric assay of hyaluronidase. J. Lab. clin. Med. 34, 74-89.

Received 17 January 1976 